\title{
Religiosity and household income in Sekhukhune
}

\author{
Philipp Öhlmann* \\ Head of the Research Programme on Religious Communities and Sustainable Development, \\ Humboldt-Universität zu Berlin \\ Research Associate, Department of Practical Theology \\ University of Pretoria
}

Silke Hüttel

Professor at the Production Economics Group

Institute of Food and Resource Economics

Rheinische Friedrich-Wilhelms-Universität Bonn

*Corresponding author: philipp.oehlmann@hu-berlin.de

This is an Accepted Manuscript of an article published by Taylor \& Francis in Development Southern Africa on 24.01.2018, available online: $\mathrm{http}: / / w w w . t a n d f o n l i n e . c o m / 10.1080 / 0376835 X .2018 .1426444$ 


\begin{abstract}
Literature analysing the interrelation of religion and economic performance suggests religion to explain differences in household income. Religious communities foster economically conducive attitudes and are important sources of social capital, particularly under weak economic structures. This paper targets at investigating effects of religiosity on rural household income using survey data from Greater Sekhukhune in the Limpopo Province of South Africa. Using insights from religious studies within a conceptual framework of rural household decision-making, the authors estimate an income equation that includes measures for religious affiliation. While church membership per se does not reveal a significant effect on household income, the results show a positive and robust relationship for membership in the Zion Christian Church and the practice of African traditional religion.
\end{abstract}

Keywords: rural households; religion; household income; Zion Christian Church; African traditional religion

JEL codes: O12; O15; Q12; Z12

\title{
Word count: 6887
}




\section{Introduction}

Recent literature concludes that research on differences in economic performance must account for political, social and cultural factors (Barro \& McCleary, 2003; Selinger, 2004). Related to this broad view on determinants of economic success in general, various studies have emphasized the role of religion (cf. de Jong, 2011). The research thus far does not yield unanimous conclusions and likely, no general answer exists. This may be because effects of religion on economic success vary across religious communities and different contexts.

Religiosity - the degree to which religion ${ }^{1}$ is relevant in daily life - can be argued to affect economic performance through its intrinsic dimension (beliefs, norms, ethics) and social dimension (social capital). Most economic research on religion and economic performance relies on Weber's (1920) notion of the Protestant Ethic to undergird empirical work: Weber suggests that by penetrating all spheres of every-day life, intrinsic religiosity changes believers' behaviour in economically favourable ways. While Weber's hypothesis has been debated for many years, the recent boom of African Initiated Churches (AICs) ${ }^{2}$, also known as 'African Reformation' (Anderson, 2001), imposes new contemporary relevance on this topic: These churches foster a similarly intensive religiosity as Weber saw it in early modern Protestantism (Meyer, B, 2004). Against this backdrop, the question arises whether AICs produce effects comparable to those initially noted by Weber.

Religious studies' research has put forward strong arguments in favour of an economically conducive role of AICs in South Africa, especially Pentecostal-Charismatic churches. However, many of these studies predominantly base their analyses on qualitative research

\footnotetext{
${ }^{1}$ Extending Iannaccone's (1998) definition, we define religion as any shared set of beliefs, activities, organisations and institutions premised on faith in supernatural forces that affect the adherents' lives and are worshipped.

${ }^{2}$ AICs are characterised by the contextual relevance of the spiritual in believers' lives. Following Anderson (2000) the term is understood here as including both Zionist/Apostolic churches as well as Pentecostal-Charismatic churches.
} 
while quantitative-econometric substantiation is lacking (e.g., Meyer, LER, 2004, Schlemmer 2008, Mafuta 2010). With this paper, we aim at contributing to closing this gap. Our objective is to investigate potential effects of religiosity on economic success. We carry out a case study to quantify whether the religiosity fostered by AICs in South Africa is conducive to economic success by econometric techniques. We hypothesize that in rural South Africa religiosity positively influences the household's economic situation and therefore reflects in higher household income. We expand the existing literature by providing a micro-level case study on a specific and limited context, the former Fetakgomo Municipality ${ }^{3}$ in the Greater Sekhukhune District of the Limpopo Province. The results contribute to the understanding of the determinants of household income in South Africa's rural north by highlighting the role of religion.

Due to their highly diverse religious landscape, the rural areas of northern South Africa provide an excellent setting for this case study. In Fetakgomo Municipality, questions on the determinants of economic success seem particularly pertinent: As a South African poverty node and part of the former Lebowa homeland ${ }^{4}$, the municipality has a weak economic base (Drimie et al., 2009; StatsSA, 2016). We hence expect social capital effects of religion to be particularly relevant. Moreover, the municipality offers a diverse religious landscape: Members of various AICs and mainline churches ${ }^{5}$ live in this region, along with people practicing African traditional religion (ATR) and nonreligious persons. At the same time, the area is relatively homogeneous in terms of economic development, sociodemographic composition and culture: It is entirely rural, incoming migration is low and $94 \%$ of the population belong to the Bapedi cultural group (StatsSA, 2016). Limiting the scope to this

\footnotetext{
${ }^{3}$ Fetakgomo Municipality was merged with Greater Tubatse Municipality in 2016. It had a population of 93795 in 22851 households (StatsSA, 2016).

${ }^{4}$ One of 10 'self-governing' areas based on the ethnic segregation of the black South African population during Apartheid.

${ }^{5}$ That is, churches emanating from a European or North American mission background.
} 
area allows us to focus on the contextually relevant categories of religion and to narrow down the possibility of unobserved factors that may confound empirical identification. We draw on insights from theology and religious studies about the mechanisms through which religiosity transmits to economic performance. Our empirical analysis is based on a conceptual framework sketching the role of religion in household decision-making - a desideratum highlighted, inter alia, by de Jong (2011). With respect to its intrinsic dimension, religiosity changes economic attitudes and constitutes emotional support. In its social dimension, religion constitutes a social capital-type resource and therefore directly relates to income.

Using data from a household survey ${ }^{6}$ conducted in 2011, we estimate a household income equation within a log-linear regression model, where we relate income to contextual categories of religious affiliation and practice. To hedge against misspecification, we carry out several robustness checks. We employ a Heckman-type approach (cf. Heckman, 1979) to test for potential selectivity biases arising from unobserved variables confounding measured impacts of religiosity and self-selection into religiosity.

The remainder of this paper is organised as follows. Section 2 provides an overview of the state of the art, followed by a description of the dataset (section 3). Section 4 outlines the analytical and empirical approaches, followed by the presentation and discussion of the results (section 5). The final section concludes.

\section{Background and literature review}

\subsection{Economic research on religion and economic success}

Economic research has investigated economic effects of religion both at the macro and micro levels. At the macroeconomic level, studies have examined the effect on economic growth

\footnotetext{
${ }^{6}$ We present a description of sampling and data collection in supplementary appendix A/2.
} 
and development caused by religious fragmentation (Montalvo \& Reynal-Querol, 2003), the shares of different religions (Noland, 2005) or aggregated indicators of belief and practice from large-scale surveys (Barro \& McCleary, 2003; Mangeloja, 2005). Analysing the impact of religion at the microeconomic level, the effects of religious affiliation and behaviour on income (Bettendorf \& Dijkgraaf, 2010, 2011; Lipford \& Tollison, 2003) and economic attitudes (Guiso et al., 2003; Brañas-Garza et al., 2009) have been investigated. ${ }^{7}$

These results, however, are highly ambiguous and no general conclusions can be drawn based on this research (cf. de Jong, 2011). While Barro \& McCleary (2003) show a positive effect of belief and a negative effect of religious practice, Bettendorf \& Dijkgraaf (2010) conclude that religious affiliation has a positive effect in high-income countries, while a negative one is found for low-income countries. Where Bettendorf \& Dijkgraaf (2011) find a negative effect of Islam, Noland (2005) shows Islam's effect to be nonnegative. Most economic studies on the relationship of religion and economic performance use cross-country or cross-regional datasets. This entails the inevitable implicit assumption that the religious categories used as explanatory variables are homogeneous. Thus, context-specific characteristics of religions are not taken into account. Moreover, empirical findings might suffer from unobserved heterogeneity such as geographical, institutional and cultural differences across countries (Guiso et al., 2003).

\subsection{Insights on religion and economic success from theology and religious studies}

In religious studies, it has been criticised (e.g. de Jong, 2011) that most of the economic research fails to lay open the transmission mechanisms and impact pathways through which religion affects economic performance. Literature from theology and religious studies may offer detailed explanations for identified effects in economic research. Most prominently,

\footnotetext{
${ }^{7}$ In supplementary appendix A/1 we provide an overview table presenting recent micro-level studies.
} 
Weber (1920) argues along the lines of an effect of religion's intrinsic dimension: religion facilitated a change in the attitudes and behaviour of the adherents of early modern Protestant denominations. Thus, their religious ethics promoted the development of capitalism. However, these Protestant ethics only developed because of an increase in the 'ecclesiasticreligious domination of life' brought about by the reformation (Weber, 1920; authors' translation). According to Weber, the increase of the relevance of religion in every-day life, that is, an increase in religiosity, was the prerequisite for an impact of religion on economic behaviour.

Another aspect of intrinsic religiosity is emotional support through religion (cf. Mangeloja, 2005). As Cilliers \& Wepener (2007) argue, religious beliefs constitute a system of values, norms, identity and transcendence that provide 'spiritual endurance'. It increases believers' resilience against adverse circumstances and external shocks, such as the death of a family member, natural catastrophes, criminal acts and poverty (cf. Masondo, 2014). This is highly relevant in contexts of high adversity, such as the poverty-stricken rural areas of South Africa.

Religiosity also affects economic success through its social dimension, which constitutes social capital - a resource that has economic returns (Knack \& Keefer, 1997; Woolcock \& Narayan, 2000). The literature suggests, first, that religious networks provide a form of risk mitigation (Dehejia et al., 2007). Second, networks reduce transaction costs (Coleman, 1988; Woolcock \& Narayan, 2000). Third, they provide club goods (Coleman, 1988). Mafuta (2010) shows this for the example of the South African Zion Christian Church (ZCC), which organizes savings groups, provides insurance schemes and conducts entrepreneurship trainings for its members. In principal, these functions are not limited to religious social capital. However, the role of religious social capital could be argued to be unique because of 
the high degree of trust and cohesion these networks command, which is constantly created and (re-)affirmed through religious ritual (Cilliers \& Wepener, 2007). Moreover, religious communities constitute the largest social networks in many developing countries.

Recent research on AICs in South Africa has highlighted that today more than half of the country's population are members of an AIC (cf. Öhlmann et al., 2016). Many of these churches foster high religiosity in both the intrinsic and the social dimension. They actively engage in the economic upliftment of their members and many of the more Pentecostal AICs preach a gospel of wealth, portraying the economic success of their members as divine promise (Cross et al., 1993; Schlemmer, 2008; Heuser, 2015). Regarding the economic effects of AICs, Garner (2000) and Dickow (2012) show a high upward social mobility of their members. Mafuta (2010) and Meyer (LER, 2004) find positive economic effects for specific denominations.

\section{Case study Fetakgomo Municipality: dataset and descriptives}

The dataset stems from a household survey conducted in Fetakgomo Municipality. Supplementary appendix A/2 provides a description of the data collection process. The survey questionnaire can be found in supplementary appendix B. We take the household head's religiosity as proxy of the entire household's religiosity, measured by affiliation with a certain type of church (Apostolic, mainline, Pentecostal-Charismatic, ZCC, St. Engenas ZCC and other churches) ${ }^{8}$, and the practice of ATR. Church membership and traditional religion are not mutually exclusive. All these religious communities foster different intensities and forms of religiosity. Moreover, we have information on two religious core dimensions according to

\footnotetext{
${ }^{8}$ Of the specific church categories, all but mainline churches can be classified as either Pentecostal-type or Pentecostal AICs (Anderson, 2000).
} 
Huber \& Huber (2012): public practice (worship attendance) and private practice (prayer frequency).

In order to measure household income, both formal and informal sector income as well as the implicit monetary value of agricultural subsistence production must be considered. We rely on a livelihood strategy based approach. That is, households were asked for any incomegenerating activities of their members and their respective monetary returns. In the case of agricultural subsistence production, monetary values were imputed. Field crop production was valued by the average quantity harvested per year, livestock and livestock products by the number/quantity produced per year and firewood by the quantity gathered. Horticultural production was valued by the area under cultivation.

\section{Table 1}

As reported in Table 1, monthly income ranges from ZAR 305 (US\$ 44) to ZAR 32735 (US\$ 4676) with the mean at ZAR 4356 (US\$ 622). ${ }^{9}$ Agriculture is the most important income source, followed by social grants and informal (self-)employment. Roughly half of the households receive remittances and only a fifth of all households have formal income at all. In terms of the mean returns, formal income is the most important income source with $\mathrm{R} 8085$ (US\$ 1155). Social grants and informal income are almost equally important with mean returns of R 1417 (US\$ 170) and R 1190 (US\$ 202), respectively (cf. Table 1).

Table 2

\footnotetext{
${ }^{9}$ US $\$$ equivalent calculated based on an exchange rate at the time of data collection of US\$ $1=$ ZAR 7 . Figures rounded to nearest US\$ 1
} 
In terms of household characteristics, we consider a dummy variable for a female household head (gender), the age of the household head (age), the number of household members (size) and the share of household members below and above working age ( $s \_$child and $s \_$pens, respectively). The majority of the households (64\%) are headed by women. Mean age of heads is 55 years (cf. Table 2) and more than half of the household members are either children $(45 \%)$ or pensioners $(14 \%)$.

The distance to the nearest tar road (road) and the distance to the nearest larger shop (shop) in kilometres capture the degree of remoteness and reflect the weak economic structures of the area. On average, households are located 3.5 kilometres away from the next tar road and nearly 20 kilometres away from the next supermarket. Human capital, as measured by the school and tertiary education of the household head (school and tertiary), offers insights in educational disadvantages. The majority of the household heads in the dataset have not completed primary education. Schooling of other household members at working age (school_o), the number of additional household members who completed a learnership (learn) or academic education ( $a c a d)$ show the educational levels of the other household members, predominantly children who have not yet moved out of the household. We also consider a dummy variable for the existence of a clinic in the village (clinic) to proxy the household's health status. Finally, to retrieve information on social capital we consider the number of groups the household is a member of (groups), such as burial societies or village committees, and by the proximity to the local chief (chief).

Mean income and mean religiosity indicators show substantial differences between religious groups (cf. Table 3). Household income of mainline church adherents is twice as high as the average in the dataset and correlated with the highest educational levels. Indicators of 
religiosity are higher in all AICs than in mainline churches. However, religiosity seems to be highest among members of Zionist churches. Members of the ZCC reported the highest prayer frequency, more than twice a day on average, and attend more congregational activities than members of all other churches. Although church membership and ATR are not mutually exclusive, the two variables are negatively correlated with a correlation coefficient of -0.64 .

Table 3 


\section{Analytical framework}

\subsection{Religion and household decision-making}

In order to investigate the impact of religion on economic success ${ }^{10}$ at household level, we draw on Becker's (1965) model of household production and Low's (1986) model of deficitproducing households in Southern Africa. This approach assumes one common household utility function and takes into account the allocation of time - a key factor influenced by religion. The household allocates time in accordance with its preferences for so-called zgoods. Such z-good is 'the seeing of a play, which depends on the input of actors, script, theatre and the playgoer's time; another is sleeping, which depends on the input of a bed, house (pills?) and time' (Becker, 1965). These goods are produced by the household according to a household production function with market goods and time as inputs. If the household prefers z-goods that require a larger share of market good inputs (such as a satellite dish) the household will allocate more time on wage labour. If the household prefers timeintensive z-goods (such as social activities), less household time will be allocated to wage labour.

Religion enters the framework in three ways. First, it is a human and social capital-type asset (Narayan \& Pritchett, 1999) increasing the market-earning potential of the household members. Second, religion is a z-good - that is, it yields utility and potentially decreases the time allocated to wage labour. Third, religion changes the household's preferences and the structure of the household's utility function, as it alters the relative valuation of z-goods. This is an economic description of the Weberian argument presented above. Such shift in preferences affects the household's economic decision-making through the allocation of the

\footnotetext{
${ }^{10}$ In the context considered here, economic success is not to imply vast wealth. In many cases the issue is survival, not prosperity (Garner 2004).
} 
household members' time. One household might diversify the income portfolio through agricultural activities, while another one might not.

In principal, an alteration of the utility function because of religiosity can increase or decrease the time allocated to wage labour and subsistence good production and hence has an ambiguous effect on the household's overall income. Based on the religious studies research cited in section 2 , we expect religiosity to shape preferences in such a way that labour supply in subsistence production and the formal and informal labour markets is increased. Furthermore, we assume that the sum of the effects described is positive and therefore religiosity increases household income.

\subsection{Empirical strategy}

To identify and quantify potential effects of religiosity on household income we resort to the following income equation (cf. Glewwe, 1991) as a basis for our empirical model. We include religiosity as additional variables on the right-hand side measured by church membership and ATR practice.

$$
\text { income }_{\mathrm{i}}=\mathrm{F}\left(\boldsymbol{a}_{\mathrm{i}}, \boldsymbol{g}_{\mathrm{i}}, \boldsymbol{h} \boldsymbol{c}_{\mathrm{i}}, \boldsymbol{s} \boldsymbol{c}_{\mathrm{i}}, \boldsymbol{r}_{\mathrm{i}}, \boldsymbol{e}_{\mathrm{i}}\right) \text {, }
$$

where $\boldsymbol{a}_{\mathrm{i}}$ is a vector of household characteristics, $\boldsymbol{g}_{\mathrm{i}}$ a vector of geographical characteristics, $\boldsymbol{h} \boldsymbol{c}_{\mathrm{i}}$ a vector of human capital characteristics, $\boldsymbol{s} \boldsymbol{c}_{\mathrm{i}}$ a vector of social capital characteristics, $\boldsymbol{r}_{\mathrm{i}}$ a vector of religiosity characteristics of household $i$. Symbol $\boldsymbol{e}_{\mathrm{i}}$ denotes an error term. Since we assume land for subsistence production to be non-scarce (Low 1986), it is not included in (1).

To estimate the income equation we use a natural logarithmic transformation of the dependent variable income. Aside from moving the distribution of the outcome variable closer to normal distribution, it is likely that the independent variables have exponential effects. For example, 
education would not increase income by a certain amount, but rather by a certain percentage, as there are various other factors influencing the outcome at the same time. Dummy variables account for the membership in one of the six church categories and the practice of traditional religion. The finally estimated empirical model is given by:

$$
\begin{aligned}
\ln \left(\text { income }_{\mathrm{i}}\right)= & \beta_{0}+\beta_{1} \text { gender }_{\mathrm{i}}+\beta_{2} \text { age }_{\mathrm{i}}+\beta_{3} \text { size }_{i}+\beta_{4} s_{-} \text {child }_{\mathrm{i}}+\beta_{5} s_{-} \text {pens }_{\mathrm{i}}+\beta_{6} \text { road }_{\mathrm{i}}+\beta_{7} \text { shop }_{\mathrm{i}} \\
& +\beta_{8} \text { school }_{\mathrm{i}}+\beta_{9} \text { tertiary }_{\mathrm{i}}+\beta_{10} \text { school }_{-} \text {o }_{\mathrm{i}}+\beta_{11} \text { learn }_{\mathrm{i}}+\beta_{12} \text { acad }_{\mathrm{i}}+\beta_{13} \text { clinic }_{\mathrm{i}} \\
& +\beta_{14} \text { group }_{\mathrm{i}}+\beta_{15} \text { chief }_{\mathrm{i}}+\beta_{16} \text { mainline }_{\mathrm{i}}+\beta_{17} z c c_{\mathrm{i}}+\beta_{18} \text { engenas }_{\mathrm{i}}+\beta_{19} \text { apostolic }_{\mathrm{i}} \\
& +\beta_{20} \text { charismatic }_{\mathrm{i}}+\beta_{21} \text { other }_{\mathrm{i}}+\beta_{22} \text { atr }_{\mathrm{i}}+e_{\mathrm{i}}
\end{aligned}
$$

Symbol $\beta_{0}$ denotes the intercept, where $\beta_{1} \ldots \beta_{22}$ denote the coefficients to be estimated. For a description of the variables, we refer to section 3.1 and table 2 . We use an ordinary least squares estimator. In order to check for robustness, we also employ non-linear version of (2), showing similar results. Given the relatively small sample at hand, we opt for the linear model.

The question arises, however, whether correlations identified using (2) can be interpreted as causal effects. As the data is non-experimental (that is, assignment of households to religious categories is not random, but by the choice of the household head), our empirical estimates may potentially suffer from selectivity issues. Unobserved heterogeneity may affect both, household income, and the decision to join a certain religious group. This could lead to biased estimates of the coefficients in (2) (cf. Cameron \& Trivedi, 2005:868). To address this issue, we test for selection bias using a Heckman (1979) two-step procedure (cf. Cameron \& Trivedi, 2005 and supplementary appendix A/3 for further details). ${ }^{11}$

\footnotetext{
${ }^{11}$ We cannot entirely rule out the possibility of a reverse relation in the sense that higher income directly affects religiosity, particularly in the ZCC. Given the case study's aim to present first insights with a rather small sample at hand, we cannot address this issue here. Larger samples with at least a repeated cross section structure would be desirable in this context.
} 


\section{Results}

In Table 4/I we present the estimation results of the log-linear income equation (2). The adjusted $\mathrm{R}^{2}$ of 0.48 indicates that the model explains nearly half the variation in household income. Eight of the coefficients are significant at least at the $5 \%$ level, four of those at the $1 \%$ level (see table 4). The sociodemographic characteristics reveal signs of the coefficients in line with the expectations and common results from household surveys. The negative coefficient of gender indicates that female-headed households have lower income. Positive coefficients of age and size show that household income increases with the age of the household head and the number of household members, respectively. Geographical factors seem to play a subordinate role, which we conjecture to be due to the relatively small geographic area covered. The positive coefficients of three of the human capital variables resonate well with human capital theory. The number of school years (school) and tertiary qualifications (tertiary) completed by the household head is positively related to income, so are the tertiary qualifications of the other household members (acad). Neither of the two social capital variables has a significant coefficient.

Two of the religion dummy variables, ZCC and ATR, have significant positive coefficients. Household income is higher when the household head is a member of ZCC or practices ATR. ${ }^{12}$ Not only are their coefficients statistically significant, their size indicates substantial economic significance as well. In order to quantify the magnitude of these coefficients, one can re-transform the model as given in (2). Membership in the ZCC increases income by the factor $e^{0.469}=1.598$, practice of ATR by the factor $e^{0.314}=1.369$. On average, members of ZCC and those practicing ATR have 59.8\% and 36.9\% higher household income, respectively. This constitutes amounts of roughly R 2600 and R 1600 when looking at the

\footnotetext{
${ }^{12}$ The fact that none of the other religion dummies has a significant coefficient does not necessarily mean that these groups do not have an effect. This could also be due to the low number of observations in these categories.
} 
mean household income of R 4356 in the dataset. In the Greater Sekhukhune District, as a poor economic context, these amounts constitute substantial differences to rural households.

\section{Table 4}

As a robustness check, we run the same model with only one dummy variable for membership in any church (cf. table 4/II). The non-significant coefficient of church indicates that church membership per se is not significantly correlated with household income when correcting for the other factors in the regression. The identified correlation from model (2) (cf. table 4/I) points to specific church categories affecting household income. As these church categories both indicate specific sets of theological tenets and specific levels of intrinsic and social religiosity (cf. table 3), we conjecture the relationship contingent on these tenets and levels of religiosity. The fact that ZCC and ATR, which constitute two very distinct belief systems, are positively related to income might indicate that levels of religiosity are more decisive than theological tenets. While we cannot fully discern this based on the data at hand, it would be consistent with the theoretical framework outlined above. The more intense religiosity is in the social dimension, the more likely it is to constitute social capital. The more intense it is in the intrinsic dimension, the more likely that it actually does alter preferences.

In order to substantiate our hypothesis of a potentially causal relationship of ZCC and ATR on household income, we use the Heckman two-step procedure to test for potential selection effects (cf. supplementary appendix A/3 where we detail the procedure). The first stage probit estimations for $z c c$, we identify chief and school_o from the probit estimation as two variables fulfilling the exclusion restriction of being uncorrelated with the outcome variable except through their correlation with $z c c$ (cf. table 5, both coefficients significantly different from 
zero at the $5 \%$ level). The probability of being a member of ZCC is higher for those household heads related to the chief and decreases with the number of school years completed by the additional adult household members. At the same time, both variables are uncorrelated with household income when correcting for membership in the ZCC (table 4/I).

\section{Table 5}

We conjecture that in the case of chief this has to do with the status of ZCC as a majority church and the fact that their theology includes elements of traditional belief systems. This includes healing, prophecy, a positive relationship with one's ancestors and protection powers against evil spirits (Anderson 2000; Mokgobi, 2014). Tradition is particularly relevant in the context of traditional royal courts. It can be assumed that people in this context (relatives, members of the court etc., as captured in the variable chief) are likely to join a church that makes reference to these beliefs. ZCC would be a preferred choice compared to other AICs because of its reputation of granting spiritual protection and because of its immense size indicating its power. At the same time, it is credible that the relationship to the chief itself does not affect household income. While the traditional authorities have important functions in the given context regarding local tradition and their offices have some administrative functions, they cannot be seen as bearers of large economic power to the extent that their royal court and extended family would substantially benefit from this (as confirmed by the nonsignificant coefficient, cf. table 4/I). The negative effect of the other household members' schooling could be explained by the fact that ZCC is a church with strong membership in rural areas and among less educated people. Hence, people from less educated households might be more likely to join the church (cf. Müller, 2011). 
In the case of practice of ATR it is more difficult to find a variable that fulfils the requirement of not being correlated with atr, but uncorrelated with household income. The only candidate from table (5) is clinic, the negative coefficient indicating a lower probability if a clinic exists in the village. Our interpretation is that the more difficult the access to health facilities, the more likely a person is to rely on traditional religion for healing purposes.

\section{Table 6}

Table 6 presents the results of the second stage estimation of the Heckman procedure where we added the inverse Mill's ratio as an additional regressor to capture possible selectivity bias (cf. supplementary appendix A/3). We cannot reject the hypothesis that these results do not suffer from selection bias, since in both cases (ZCC membership and practice of ATR) the respective coefficients are not significantly different from zero at any usual level. The results, however, must be interpreted in the context of the case study with relatively low number of observations and, in the case of atr, relatively weak explanatory power in the first-stage probit model.

\section{Concluding remarks}

Based on a household survey in the Greater Sekhukhune District, we investigate the relation between religiosity and rural household income. Using a regression-based approach, we explain household income by measures of socio-demographic characteristics, geography, human and social capital as well as indicators of church membership and the practice of African traditional religion. We find two indicators of religiosity to be strongly correlated with household income: membership in the Zion Christian Church and the practice of African 
Traditional Religion. This correlation is specific to the ZCC; no other church category reveals a relevant relation to household income.

A crucial question is whether these correlations can be interpreted as causal effects. Relying on evidence from recent research in theology and religious studies, we find that membership in ZCC and practice of ATR have a potentially causal impact on household income. This is substantiated by a Heckman two-step procedure, though acknowledging the relatively small sample.

It is important to note three caveats regarding our empirical procedure. First, the results must be interpreted in the context of the relatively small sample. While we conclude that membership in the ZCC has an effect on household income, we cannot conclude that this is the only church in which membership goes along with increased economic success. Second, the Heckman test depends on the strength of the identifying variables. While based on our estimations we can be relatively confident about those factors determining ZCC membership, the identifying variable for practice of ATR is relatively weak. Hence, the causal interpretation of ATR needs to be treated with caution. Third, our data is statistically representative only for the geographical area of the former Fetakgomo Municipality. However, we reckon that the results possess external validity for similar rural former homeland areas in Sekhukhune and neighbouring districts in the Limpopo Province, because of their similar economic, demographic, cultural and religious structures.

Notwithstanding these limitations, our results provide quantitative empirical evidence that religiosity does influence economic success in the region studied. This effect, however, does not appear to be an influence of religious affiliation and church membership per se, but rather 
to be contingent on specific patterns of social or intrinsic religiosity fostered in a religious community or, potentially, its dominant theological tenets. In particular, such patterns seem to exist in the ZCC. Our results are in line with the religious studies research arguing that many AICs promote economic upliftment (Cross et al., 1993; Schlemmer, 2008; Öhlmann et al., 2016). Possibly, such patterns also exist in ATR.

An impact of traditional religious practice on economic success has to the best of our knowledge thus far not been documented. How this specific religiosity might transmit to household income remains for future studies to discern. The ZCC, on the other hand, has been documented as a church fostering high degrees of religiosity among its members (in the Weberian sense as ecclesiastic-religious domination of life) and as promoting economically conducive attitudes (Mafuta 2010). Hence, the results resonate well with Weber's hypothesis that increased religiosity leads to improved economic outcomes. Moreover, this church constitutes a network with millions of members and provides its members with various social capital-type resources, which directly relates to social capital theory. From our data, both seem plausible. ZCC members have the highest indicators of religiosity in the dataset both in the individual and in the social dimension.

We see our analysis as a starting point in the quantitative analysis of the effects of religiosity on economic success in the rural areas of South Africa. Particularly three points merit further attention. First, comparative studies in other areas would provide insights as to whether the results are context-specific or possess cross-contextual validity. This might also yield an indication as to whether effects can be identified for other religious communities. Second, analyses based on larger samples (and potentially using panel data) would enable the use of more sophisticated econometric techniques required to further substantiate causal impacts of 
religion on economic success. Third, in order to elucidate the actual transmission mechanisms of religiosity to economic success, in-depth analysis of these mechanisms is needed, particularly with respect to the religious communities highlighted above. 


\section{References}

Anderson, A, 2000. Zion and Pentecost. The spirituality and experience of Pentecostal and Zionist/ Apostolic churches in South Africa. University of South Africa Press, Pretoria.

Anderson, A, 2001. African Reformation. African Initiated Christianity in the $20^{\text {th }}$ Century. Africa World Press, Trenton.

Barro, RJ, \& McCleary, RM, 2003. Religion and economic growth across countries. American Sociological Review 68, 760-81.

Bettendorf, L, \& Dijkgraaf, E, 2010. Religion and income: Heterogeneity between countries. Journal of Behaviour and Organization 74, 12-29.

Bettendorf, L, \& Dijkgraaf, E, 2011. The Bicausal Relation between Religion and Income. Applied Economics 43, 1351-63.

Brañas-Garza, P, Rossi, M, \& Zaclicever, D, 2009. Individual's religiosity enhances trust: Latin American evidence for the puzzle. Journal of Money, Credit and Banking 41, $555-66$.

Cameron, CA, \& Trivedi PK, 2005. Microeconometrics. Methods and applications. Cambridge University Press, Cambridge.

Cilliers, J, \& Wepener, C, 2007. Ritual and the generation of social capital in contexts of poverty: A South African exploration.” International Journal of Practical Theology $11,39-55$.

Coleman, JS, 1988. Social capital in the creation of human capital. The American Journal of Sociology 94, Supplement: Organizations and Institutions: Social and Economic Approaches to the Analysis of Social Structure, 95-120. 
Cross, C, Oosthuizen, GC, \& Clark, C, 1993. Out of the wind: The African Independent Churches and youth urbanization in Metropolitan Natal. A report prepared for the Co-operative Programme on the Youth, Durban.

De Jong, E, 2011. Religious values and economic growth: A review and assessment of recent rtudies.” In Ter Haar, G (Ed.), Religion and development. Ways of transforming the world. Columbia University Press, New York, 111-40.

Drimie, S, Germishuyse, T, Rademeyer, L \& Schwabe, C., 2009. Agricultural production in Greater Sekhukhune: the future for food security in a poverty node of South Africa? Agrekon 48, 245-75.

Dehejia, R, DeLeire, T \& Luttmer EFP, 2007. Insuring consumption and happiness through religious organizations. Journal of Public Economics 91, 259-79.

Dickow, H, 2012. Religion and attitudes towards life in South Africa. Pentecostals, charismatics and reborns. Nomos, Baden-Baden.

Garner, RC, 2000. Religion as a source of social change in the New South Africa. Journal of Religion in Africa 30, 310-43.

Garner, RC, 2004. African Independent Churches and economic development in Edendale. In Venter, D (Ed.), Engaging modernity. Methods and cases for studying African Independent Churches in South Africa. Prager, Westport, 81-103.

Glewwe, P, 1991. Investigating the determinants of household welfare in Côte d'Ivoire. Journal of Development Economics 35, 307-37.

Guiso, L, Sapienza, P \& Zingales, L, 2003. People's opium? Religion and economic attitudes. Journal of Monetary Economics 50, 225-82.

Heckman, JJ, 1979. Sample selection bias as a specification error. Econometrica 47, 153-61.

Heuser, A (Ed.), 2015. Pastures of Plenty: Tracing Religio-scapes of Prosperity Gospel in Africa and Beyond. Peter Lang, Frankfurt. 
Huber, S, \& Huber, O, 2012. The centrality of religiosity scale (CRS). Religions 3, 710-24.

Iannaccone, LR, 1998. Introduction to the economics of religion. Journal of Economic Literature 36, 1465-96.

Knack, S, \& Keefer, P, 1997. Does social capital have an economic payoff? A cross-country investigation. Quarterly Journal of Economics 112, 1251-88.

Lipford, JW, \& Tollison, RD, 2003. Religious participation and income. Journal of Economic Behaviour \& Organization 51, 249-60.

Low, A, 1986. Agricultural development in Southern Africa. Farm-household conomics and the food crisis. James Currey. London.

Mafuta, L, 2010. Religion and development in South Africa: an investigation of the relationship between soteriology and capital development in an African Initiated Church (AIC), PhD thesis, University of South Africa.

Mangeloja, E, 2005. Economic growth and religious production efficiency. Applied Economics 37, 2349-59.

Masondo, ST, 2014. The African indigenous churches' spiritual resources for democracy and social cohesion, Verbum et Ecclesia 35. http://dx.doi.org/10.4102/ve.v35i3.1341. Accessed 1 August 2017.

Meyer, B, 2004. Christianity in Africa: From African independent to Pentecostal-charismatic churches. Annual Review of Anthropology 33, 447-74.

Meyer, LER, 2004. The Pentecostal movement as represented in Breakthrough International. An expression of missio dei? A contribution to an experiental pneumatology of mission. PhD thesis, University of KwaZulu-Natal.

Mokgobi, MG, 2014. Understanding traditional African healing. African Journal for Physical Health Education, Recreation, and Dance 20, 24-34. 
Montalvo, JG, \& Reynal-Querol, M, 2003. Religious polarization and economic development. Economics Letters 80, 201-10.

Müller, R, 2011. African Pilgrimage: Ritual Travel in South Africa's Christianity of Zion. Ashgate, Surrey.

Narayan, D, \& Pritchett, L, 1999. Cents and sociability: Household income and social capital in rural Tanzania. Economic Development and Cultural Change 47, 871-97.

Noland, M, 2005. Religion and economic performance. World Development 33, 1215-32.

Öhlmann, P, Frost, M-L, \& Gräb, W, 2016. African Initiated Churches' potential as development actors, HTS Theological Studies 72, http://dx.doi.org/10.4102/hts.v72i4.3825. Accessed 1 August 2017.

Schlemmer, L, 2008. Dormant Capital: The Pentecostal Movement in South Africa and its Potential Social and Economic Role. Centre for Development and Enterprise, Johannesburg.

Selinger, L, 2004. The forgotten factor: The uneasy relationship between religion and development. Social Compass 51, 523-43.

StatsSA (Statistics South Africa), 2016. Statistics by place: Fetakgomo. http://www.statssa.gov.za/?page_id=993\&id=fetakgomo-municipality. Accessed 11 April 2016.

Weber, M, (1920) 2002. Die protestantische Ethik und der 'Geist' des Kapitalismus. In Kaesler, D (Ed.), Max Weber. Schriften 1894-1922. Kröner, Stuttgart, 150-226.

Woolcock, M, \& Narayan, D, 2000. Social capital: Implications for development theory, research, and policy. The World Bank Research Observer 15, 225-49. 


\section{List of tables}

Table 1: Income sources in Fetakgomo

Table 2: Descriptive statistics

Table 3: Religious groups' profiles

Table 4: Estimation results log-linear income equation

Table 5: Probit estimates of membership in the ZCC and practice of ATR

Table 6: Estimation results log-linear model with Heckman's $\lambda$ 
Table 1: Income sources in Fetakgomo

\begin{tabular}{|c|c|c|c|}
\hline \multirow{2}{*}{$\begin{array}{l}\text { Income source } \\
\text { Agriculture }\end{array}$} & \multirow{2}{*}{$\begin{array}{l}\% \text { of households } \\
\text { receiving income } \\
\text { from the source }\end{array}$} & \multicolumn{2}{|c|}{$\begin{array}{c}\text { Mean monetary return } \\
\text { per month in ZAR }\end{array}$} \\
\hline & & & \\
\hline Field crops & 41 & 146 & $(206)$ \\
\hline Vegetables & 29 & 98 & $(259)$ \\
\hline Livestock & 53 & 391 & $(764)$ \\
\hline Fruit & 56 & 24 & $(32)$ \\
\hline Gathering wood & 69 & 137 & $(113)$ \\
\hline Agriculture total & 94 & 429 & $(673)$ \\
\hline \multicolumn{4}{|l|}{ Other income sources } \\
\hline Formal income (excluding social grants) & 23 & 8085 & (7 835) \\
\hline Informal income & 53 & 1190 & $\left(\begin{array}{lll}1 & 395\end{array}\right)$ \\
\hline Remittances & 39 & 818 & $(680)$ \\
\hline Social grants & 78 & 1417 & $(868)$ \\
\hline
\end{tabular}

Note: Standard deviation in brackets; amounts rounded to nearest ZAR 1; N=180. 
Table 2: Descriptive statistics

\begin{tabular}{|c|c|c|c|c|}
\hline Variable & Min. & Max. & Mean & Std. dev. \\
\hline Income (ZAR) & 305 & 32735 & 4356 & 4933 \\
\hline \multicolumn{5}{|l|}{ Household demographics } \\
\hline gender $[1=$ female $]$ & \multicolumn{2}{|l|}{ dummy } & \multicolumn{2}{|l|}{.64} \\
\hline age [years] & 21 & 101 & 54.67 & 14.97 \\
\hline size [number of household members] & 1 & 15 & 4.80 & 2.44 \\
\hline s_child [share of household members below age 18] & 0 & 1 & .45 & .28 \\
\hline s_pens [share of household members above age 65] & 0 & 1 & .14 & .21 \\
\hline \multicolumn{5}{|l|}{ Geography: } \\
\hline road [distance to nearest tar road in $\mathrm{km}$ ] & 0 & 18 & 3.58 & 3.95 \\
\hline shop [distance to closest supermarket in $\mathrm{km}$ ] & 0 & 75 & 18.53 & 18.13 \\
\hline \multicolumn{5}{|l|}{ Human capital } \\
\hline school [school years completed by household head] & 0 & 12 & 5.76 & 4.84 \\
\hline $\begin{array}{l}\text { tertiary [tertiary education completed by household head, } \\
1=\text { learnership, } 2=\text { college/university] }\end{array}$ & 0 & 2 & .19 & .53 \\
\hline $\begin{array}{l}\text { school_o [mean school years completed by adult } \\
\text { household members, except household head] }\end{array}$ & 0 & 12 & 8.28 & 2.89 \\
\hline $\begin{array}{l}\text { learn [number of adult household members with } \\
\text { completed learnership, except household head] }\end{array}$ & 0 & 2 & .12 & .34 \\
\hline $\begin{array}{l}\text { acad [number of adult household members with completed } \\
\text { college/university, except household head] }\end{array}$ & 0 & 2 & .09 & .30 \\
\hline clinic $[1=$ clinic in village $]$ & \multicolumn{2}{|l|}{ dummy } & .69 & \\
\hline Social capital & & & & \\
\hline group [number of groups household head is a member of] & 0 & 4 & 1.40 & .74 \\
\hline $\begin{array}{l}\text { chief [household head's relation to chief, } 1=\text { distant family } \\
\text { or council member, } 2=2^{\text {nd }} \text { degree relation or distant } \\
\text { relation and council member, } 3=1^{\text {st }} \text { degree relation or } \\
\text { relation and senior councillor] }\end{array}$ & 0 & 3 & .56 & .81 \\
\hline
\end{tabular}

Note: $\mathrm{N}=180$. 


\begin{tabular}{|c|c|c|c|c|c|}
\hline & $\begin{array}{c}\text { Household income } \\
\text { in ZAR }\end{array}$ & $\begin{array}{l}\text { School years } \\
\text { completed }\end{array}$ & $\begin{array}{c}\text { Weekly } \\
\text { church } \\
\text { service } \\
\text { attendance }\end{array}$ & $\begin{array}{c}\text { Weekly } \\
\text { other } \\
\text { church } \\
\text { activities } \\
\text { attendance }\end{array}$ & $\begin{array}{l}\text { Weekly } \\
\text { prayer } \\
\text { frequency }\end{array}$ \\
\hline All observations & 4356 (4 933) & $5.76(4.84)$ & & $\mathrm{n} / \mathrm{a}$ & \\
\hline $\begin{array}{l}\text { Apostolic churches }(12.8 \%) \\
\text { apostolic }\end{array}$ & $3006 \quad(2158)$ & $5.78(4.55)$ & $1.52(1.37)$ & $.57(.51)$ & $13.09(5.30)$ \\
\hline $\begin{array}{l}\text { Pentecostal-Charismatic } \\
\text { churches }(8.3 \%) \text { charismatic }\end{array}$ & $5078 \quad(8034)$ & $7.60(5.58)$ & $1.65(1.34)$ & $1.06(.70)$ & $12.83(8.12)$ \\
\hline $\begin{array}{l}\text { Mainline churches }(5.0 \%) \\
\text { mainline }\end{array}$ & $10718(10556)$ & $9.33(3.87)$ & $1.08 \quad(.77)$ & $.47(.71)$ & $12.37(4.64)$ \\
\hline $\begin{array}{l}\text { Zion Christian Church }(20.0 \%) \\
z c c\end{array}$ & 4216 (3 875) & $6.08(5.01)$ & $1.78 \quad(.87)$ & $1.28(.70)$ & $14.44(6.57)$ \\
\hline $\begin{array}{l}\text { St. Engenas Zion Christian } \\
\text { Church }(12.8 \%) \text { engenas }\end{array}$ & 3264 (1988) & $5.61(4.75)$ & $2.38(1.20)$ & $1.00(.91)$ & $12.75(5.83)$ \\
\hline Other churches $(2.8 \%)$ other & $4285 \quad(1053)$ & $7.40(4.98)$ & $1.20(.45)$ & $.80(.84)$ & $8.80(5.17)$ \\
\hline All churches $(61.7 \%)$ & $4415 \quad(5184)$ & $6.45(5.90)$ & $1.75(1.15)$ & $.96(.77)$ & $13.17(6.21)$ \\
\hline $\begin{array}{l}\text { African traditional religion } \\
(43.9 \%) a t r\end{array}$ & 4958 (5 974) & $4.77(4.79)$ & & $\mathrm{n} / \mathrm{a}$ & \\
\hline
\end{tabular}

Notes: Standard deviation in brackets; household income rounded to nearest ZAR 1; N=180. 
Table 4: Estimation results log-linear income equation

\begin{tabular}{|c|c|c|c|c|}
\hline & Coefficient & $\begin{array}{c}\text { Standard } \\
\text { error }\end{array}$ & Coefficient & $\begin{array}{c}\text { Standard } \\
\text { error }\end{array}$ \\
\hline Constant & $6.184 * * *$ & .440 & $6.460 * * *$ & .432 \\
\hline \multicolumn{5}{|c|}{ Household demographics } \\
\hline gender & $-.344 * * *$ & .106 & $-.286^{* * *}$ & .107 \\
\hline age & $.016^{* *}$ & .006 & $.012 * *$ & .006 \\
\hline size & $.096 * * *$ & .026 & $.101 * * *$ & .026 \\
\hline s_child & -.179 & .236 & -.185 & .239 \\
\hline s_pens & .166 & .327 & .266 & .332 \\
\hline \multicolumn{5}{|l|}{ Geography } \\
\hline road & $-.024 *$ & .014 & $-.023 *$ & .014 \\
\hline shop & .004 & .003 & .004 & .003 \\
\hline \multicolumn{5}{|l|}{ Human capital } \\
\hline school & $.034 * *$ & .015 & $.029 * *$ & .015 \\
\hline tertiary & $.648 * * *$ & .103 & $.683^{* * *}$ & .101 \\
\hline school_o & .008 & .017 & .003 & .018 \\
\hline learn & .231 & .155 & .213 & .158 \\
\hline acad & $.363 * *$ & .169 & $.385^{* *}$ & .171 \\
\hline clinic & .028 & .105 & .061 & .107 \\
\hline \multicolumn{5}{|l|}{ Social capital } \\
\hline group & .064 & .069 & .034 & .069 \\
\hline chief & -.086 & .061 & -.088 & .061 \\
\hline \multicolumn{5}{|l|}{ Religious groups } \\
\hline mainline & .286 & .241 & & \\
\hline$z c c$ & $.469 * * *$ & .160 & & \\
\hline engenas & .166 & .173 & & \\
\hline apostolic & -.156 & .166 & & \\
\hline charismatic & .268 & .204 & & \\
\hline other & .372 & .313 & & \\
\hline church & & & .181 & .129 \\
\hline atr & $.314 * *$ & .124 & $.314 * *$ & .124 \\
\hline
\end{tabular}

Notes: Dependent variable: $\ln ($ income $) ; \mathrm{N}=180 ;$ Adjusted $\mathrm{R}^{2}=.48(\mathrm{I}) / .45(\mathrm{II}) .{ }^{*} \mathrm{p}<.1, * * \mathrm{p}<.05, * * * \mathrm{p}<.01$. 
Table 5: Probit estimates of membership in the ZCC and practice of ATR

\begin{tabular}{|c|c|c|c|c|c|c|}
\hline & \multicolumn{3}{|c|}{ Membership in ZCC } & \multicolumn{3}{|c|}{ Practice of ATR } \\
\hline & Coefficient & $\begin{array}{c}\text { Standard error } \\
\text { (asymptotic) }\end{array}$ & $\begin{array}{c}\text { Wald } \\
\text { statistic }\end{array}$ & Coefficient & $\begin{array}{c}\text { Standard error } \\
\text { (asymptotic) }\end{array}$ & $\begin{array}{c}\text { Wald } \\
\text { statistic }\end{array}$ \\
\hline constant & -.828 & 1.154 & .515 & -1.079 & 1.081 & .996 \\
\hline gender & $.832 * * *$ & .350 & 5.658 & -.404 & .265 & 2.323 \\
\hline school_o & $-.110 * *$ & .050 & 4.910 & -.010 & .046 & .051 \\
\hline clinic & .180 & .298 & .367 & $-.516^{*}$ & .265 & 3.806 \\
\hline chief & $.334 * *$ & .163 & 4.181 & .087 & .149 & 0.344 \\
\hline church & & & & $-2.027 * * *$ & .269 & 56.990 \\
\hline atr & $-1.120^{* * *}$ & .307 & 13.310 & & & \\
\hline
\end{tabular}

Notes: Dependent variables: $\operatorname{prob}(z c c=1), \operatorname{prob}(a t r=1) ; \mathrm{N}=180 ; \mathrm{McFadden}$ Pseudo $\mathrm{R}^{2}=0.24$ (ZCC model), 0.377 (ATR model). ${ }^{*} \mathrm{p}<.1, * * \mathrm{p}<.05, * * * \mathrm{p}<.01$. Non-significant coefficients omitted. 
Table 6: Estimation results log-linear model with Heckman's $\lambda$

\begin{tabular}{|c|c|c|c|c|}
\hline & \multicolumn{2}{|c|}{ Estimation with ZCC } & \multicolumn{2}{|c|}{ Estimation with ATR } \\
\hline & Coefficient & Standard Error & Coefficient & Standard Error \\
\hline constant & $6.505 * * *$ & .465 & $6.627 * * *$ & .478 \\
\hline gender & $-.281 * *$ & .112 & $-.318 * *$ & .103 \\
\hline age & $.012 *$ & .007 & $.012 * *$ & .006 \\
\hline size & $.092 * * *$ & .026 & $.092 * * *$ & .022 \\
\hline s_child & -.084 & .244 & & \\
\hline s_pens & .216 & .347 & .281 & .322 \\
\hline road & $-.027 *$ & .015 & $-.025^{*}$ & .014 \\
\hline shop & .004 & .003 & .004 & .003 \\
\hline school & $.031 * *$ & .016 & $.029 * *$ & .015 \\
\hline tertiary & $.671 * * *$ & .100 & $.698 * * *$ & .103 \\
\hline school_o & & & .004 & .018 \\
\hline learn & .218 & .153 & .226 & .155 \\
\hline acad & $.391 * *$ & .167 & $.414 * *$ & .171 \\
\hline clinic & .054 & .107 & & \\
\hline groups & .056 & .069 & & \\
\hline chief & & & -.079 & .059 \\
\hline church & & & .058 & .286 \\
\hline$z c c$ & .481 & .501 & & \\
\hline$a t r$ & .185 & .123 & .056 & .550 \\
\hline$\lambda_{I}$ & -.092 & .185 & .045 & .172 \\
\hline$\lambda_{0}$ & 1.531 & 1.957 & .939 & 1.379 \\
\hline
\end{tabular}

Notes: Dependent variable: $\ln ($ income $) ; \mathrm{N}=180$; Adjusted $\mathrm{R}^{2}=.46 . * \mathrm{p}<.1, * * \mathrm{p}<.05, * * * \mathrm{p}<.01$. Standard errors corrected according to Heckman (1979). 